\title{
Polychaeta (Annelida) associated with Thalassia testudinum in the northeastern coastal waters of Venezuela
}

\author{
Ildefonso Liñero Arana \& Oscar Díaz Díaz \\ Instituto Oceanográfico de Venezuela, Cumaná, Estado Sucre, Venezuela, Apdo. 245; ilinero@cantv.net
}

\author{
Received 20-XI-2002. C Corrected 12-III-2004. Accepted 09-III-2006.
}

\begin{abstract}
Seasonal variations of polychaetes in a Thalassia testudinum bed were studied from June 2000 to April 2001 in Chacopata, northeastern Venezuela. Eight replicate samples were taken monthly with a $15 \mathrm{~cm}$ diameter core and the sediment was passed through a $0.5 \mathrm{~mm}$ mesh sieve. A total of 1013 specimens, belonging to 35 species, was collected. The monthly density ranged from $387 \mathrm{ind} / \mathrm{m}^{2}$ (September) to $1735 \mathrm{ind} / \mathrm{m}^{2}$ in May $\left(\overline{\mathrm{X}}=989 \pm 449 \mathrm{ind} / \mathrm{m}^{2}\right)$. Species richness was lowest in August and September (8) and highest (25) in April $(\bar{X}=18.00 \pm 5.29)$. The shoot density of Thalassia showed an average of $284 \pm 77.60$ shoots $/ \mathrm{m}^{2}$, with extreme values in February (164) and May (422). Species diversity ranged from 1.25 in August and 3.33 bits/ind in December $(\bar{X}=2.47 \pm 0.64)$. Significant positive correlations were detected among the number of Thalassia shoots, polychaete abundance and species richness, as well as among species richness, polychaete abundance and species diversity. Species number and average density were found within the intervals of mean values reported in similar studies. The higher number of species and organisms obtained in March-April and June-July can be attributed to the recruitment correlated with the regional up-welling. Rev. Biol. Trop. 54 (3): 971-978. Epub 2006 Sept. 29.
\end{abstract}

Key words: macrofauna, benthos, Thalassia testudinum, Annelida, Polychaeta.

Coastal seagrass meadows are recognized as highly productive ecosystems (Lewis 1977, Kitting 1984, Kjerfve et al. 1998). These seagrasses develop as a result of the combined action of several local factors, such as light, temperature, salinity, sediment type and nutrient availability (Orth and Moore 1986, Short 1987, Giesen et al. 1990, Pedersen and Borum 1993, Hemminga et al. 1994, Terrados et al. 1998). Seagrasses are the refuge and breeding grounds of numerous invertebrates and fishes (den Hartog 1967, Lewis and Stoner 1983), which is why species abundance and diversity are higher there than in areas without this vegetation (Stoner 1980, Lewis and Stoner 1983, Virnstein et al. 1983, Orth et al. 1984, Summerson and Peterson 1984, Schneider and Mann 1991, Connolly 1997). Polychaetes are often the group with the highest species richness and/or abundance in the invertebrate community of seagrass beds (O'Gower and Wacasey 1967, Lewis and Stoner 1983, Cruz-Ábrego et al. 1994), and they play a remarkably important role in the structure of these communities.

In the coastal waters of the Gulf of Mexico and the Caribbean Sea, T. testudinum is the most extensive seagrass, and its ecological importance is comparable to that of coral reefs and swamps; however, its beds are being progressively disturbed by coastal development and other human activities (Kjerfve et al. 1998). Venezuela, where an increase in the indiscriminate use coastal areas has had a severe impact on shallow communities, is no exception.

For this reason, it was considered of interest to begin a series of studies to gather information on the community structure of the macrofauna found in $T$. testudinum beds off the northeastern coast of Venezuela, where some meadows have not yet been impacted 
anthropogenically. In this study, we will analyze the seasonal variations of polychaetes in a seagrass bed located far from any source of pollution or human interference. We selected this group because among the dominant groups of benthic macrofauna, they are possibly the most vulnerable to predators and natural or anthropogenic perturbations. In addition, the polychaetes lack a protective exoskeleton and lack or have poor displacement capacities.

\section{MATERIALS AND METHODS}

The Chacopata beach $\left(10^{\circ} 40^{\prime} 00^{\prime \prime} \mathrm{N}\right.$, $\left.63^{\circ} 49^{\prime} 18^{\prime \prime} \mathrm{W}\right)$ has highly turbid waters and sandy sediment with a high content of biogenic material, especially rich in bivalve shell fragments. In Venezuela there are two clearly differentiated climatic seasons, a dry period from November to April, with relatively low temperatures and strong trade winds, and a rainy period during the remaining months, with opposite characteristics.

Monthly benthic samples were collected from a Thalassia bed from June 2000 to May 2001 at depths of between 0.5 and $1.5 \mathrm{~m}$. Eight replicate samples were taken with a 15 $\mathrm{cm}$ diameter core and forced approximately $25 \mathrm{~cm}$ deep into the sediment. Core samples were passed through a $0.5 \mathrm{~mm}$ mesh sieve, the number of T. testudinum shoots was counted, and the polychaetes were preserved in an $8 \%$ formaline seawater solution. During each sampling, measures of salinity (using a temperature compensated refractometer) and the bottom water temperature were taken. Temperature was measured at approximately the same time every day (09:00), since this parameter presents diurnal variations as a consequence of shallow depth. An additional $15 \mathrm{~cm}$ sample from the superficial sediment layer was taken with the same core for granulometric analysis.

We calculated species constancy, the biological dominance index (McCloskey 1970), Shannon's species diversity H' $=-\sum \mathrm{p}_{\mathrm{i}} \log _{2} \mathrm{p}_{\mathrm{i}}$, and evenness $\mathrm{E}=\mathrm{H}^{\prime} / \log _{2} \mathrm{~S}$ (Pielou 1966). A one-way ANOVA was applied to evaluate temporal variations in polychaetes counts. To achieve homogeneity of variances, densities were transformed to $\log _{10}(n+1)$. Pearson's correlation analysis among the different variables was performed. The Jaccard's similarity index was calculated, as well as the corresponding dendrogram, using the groupaverage clustering method.

\section{RESULTS}

Bottom water temperature varied seasonally with a maximum $\left(27.5-29.1^{\circ} \mathrm{C}\right)$ between June and October, and a minimum (26.1$27.4^{\circ} \mathrm{C}$ ) between November and May. Salinity ranged from 35 to $37 \%$, with its highest values between January and April. Granulometric analyses showed moderately to poorly sorted sediments, with mean grain sizes corresponding to medium and fine sands, with averages of $31.37 \%$ and $25.81 \%$ respectively.

Species composition and polychaete abundance averages are shown in Table I. Thirty five species from 1013 organisms were collected. Average density was $989.36 \pm 448.36$ ind $/ \mathrm{m}^{2}$, and Kinbergonuphis sp. was the species that recorded the highest density ( $\overline{\mathrm{X}}=$ $543.03 \pm 254.98 \mathrm{ind} / \mathrm{m}^{2}, 54.89 \%$ ). This species also recorded the highest constancy of occurrence (100\%), followed by Naineris laevigata (Grube 1855) (91.67\%) and Diopatra cuprea Bosc 1802, Lumbrineris latreilli (Audouin and Milne-Edwards 1834) and three species, Haplosyllis spongicola (Grube 1855) with equal constancies $(83.33 \%)$. Kinbergonuphis sp. was the most abundant species as measured using the McCloskey (1970) dominance index, with a value of 100 ; other dominant species included N. laevigata (81.82), L. latreilli (61.09) and D. cuprea (56). Onuphids constituted the most important family, since their four species contributed to $60.12 \%$ of total abundance. Polychaetes that build emergent tubes (onuphids, terebellids) made up $63.57 \%$ of the polychaete fauna.

The monthly species richness average was $18 \pm 5.29$ species (Fig. 1), with its lowest 


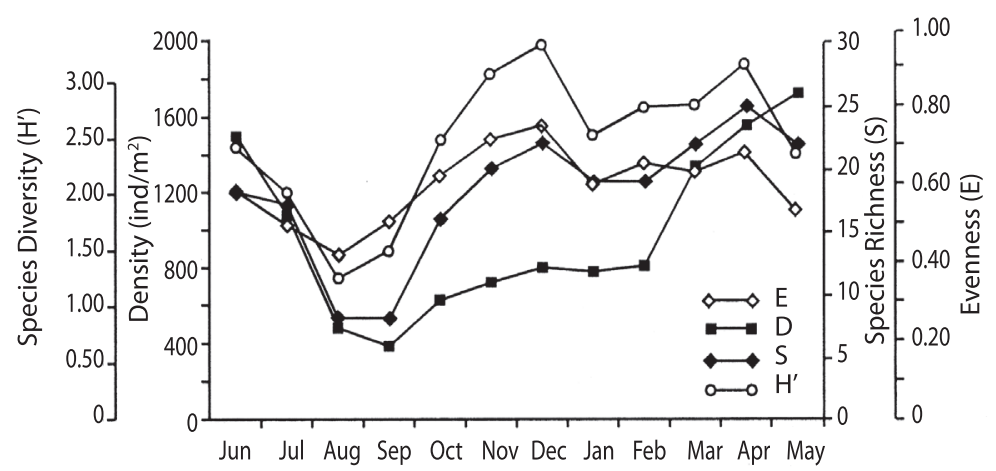

Fig. 1. Monthly values of species richness $(\mathrm{S})$, density $\left(\mathrm{D}\right.$, ind $\left./ \mathrm{m}^{2}\right)$, diversity $\left(\mathrm{H}^{\prime}\right)$ and evenness (E) during the period studied.

values in August and September (eight species) and highest values in April (25), and 22 in December, March and May. Monthly density ranged from $387 \mathrm{ind} / \mathrm{m}^{2}$ (October 2001) to $1735 \mathrm{ind} / \mathrm{m}^{2}$ (May 2001). Species richness and density showed similar monthly trends (Fig. 1), decreasing from the beginning of June until August-September and then progressively increasing in November and December.

Species diversity, as measured by the Shannon diversity index, ranged from 1.25 in August to 3.33 bits/ind in December $(\overline{\mathrm{X}}=2.47 \pm 0.64)$. Evenness, as measured by the Pielou index, showed a minimum in August $(0.42)$ and a maximum in December $(0.75)$ $(\bar{X}=0.60 \pm 010)$. Monthly changes in these two parameters occurred in parallel (Fig. 1). Monthly shoot density of Thalassia presented an average of $284 \pm 77.60$ shoots $/ \mathrm{m}^{2}$, with values ranging from 164 in February to 422 in May.

Significant differences in density were detected among the different months (Fisher, $\mathrm{p}<0.05)$. A significant positive Pearson's correlation was found with the number of Thalassia shoots, polychaete abundance $(\mathrm{r}=0.59, \mathrm{p}<0.05)$ and species richness $(\mathrm{r}=0.58, \mathrm{p}<0.05)$, and also with species richness, abundance $(\mathrm{r}=0.74$, $\mathrm{p}<0.01)$ and diversity $(\mathrm{r}=0.89, \mathrm{p}<0.001)$.

Cluster analysis produced five poorly separated groups (Fig. 2) with the exception of December; the main group consisted of 7 months.

\section{DISCUSSION}

The efficiency of macrofauna collection, particularly in relation to species composition and abundance, may be influenced by the sampling methodology (Lewis and Stoner 1983). In previous studies done on Thalassia beds, different collection methodologies linked with sample size, number of replicate samples, screen mesh size, core depth, etc., have been used (Table 1), which makes the comparisons between species composition and abundance

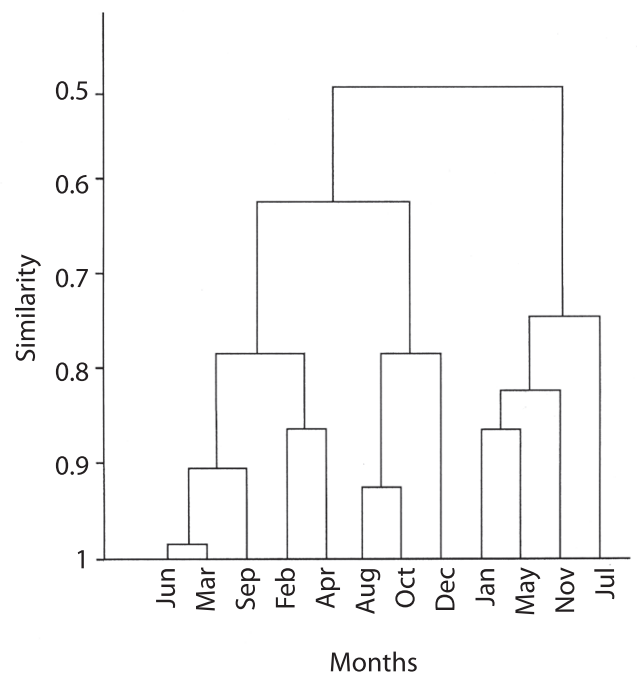

Fig. 2. Dendrogram grouping collections using group-average clustering strategy. 
TABLE 1

Polychaetes collected in Chacopata beach, Venezuela

\begin{tabular}{|c|c|c|c|c|c|}
\hline Species & $\mathrm{TC}$ & $\mathrm{D}$ & SD & BID & $\mathrm{C}$ \\
\hline Americonuphis magna & $\mathrm{O}$ & 8.79 & 10.15 & 25.09 & 50.00 \\
\hline Kinbergonuphis sp. & DF & 543.03 & 254.98 & 100.00 & 100.00 \\
\hline Diopatra tridentata & $\mathrm{C}$ & 11.72 & 14.13 & 28.55 & 50.00 \\
\hline Diopatra cuprea & DF-O & 31.25 & 27.97 & 56.00 & 83.33 \\
\hline Eunice vittata & $\mathrm{C}$ & 10.74 & 11.68 & 36.00 & 58.33 \\
\hline Eunice antennata & $\mathrm{C}$ & 9.77 & 12.07 & 26.18 & 41.67 \\
\hline Marphysa sanguinea & $\mathrm{O}$ & 13.67 & 13.06 & 40.18 & 58.33 \\
\hline Streblosoma hartmanae & $\mathrm{DF}$ & 5.86 & 7.90 & 19.27 & 33.33 \\
\hline Polydora sp. & DF & 4.88 & 9.29 & 15.09 & 25.00 \\
\hline Prionospio heterobranchia & DF & 13.67 & 14.85 & 28.55 & 58.33 \\
\hline Hemipodus olivieri & DF & 5.86 & 10.60 & 11.45 & 33.33 \\
\hline Lumbrineris latreilli & $\mathrm{O}$ & 25.39 & 20.50 & 61.09 & 83.33 \\
\hline Arabella iricolor & $\mathrm{C}$ & 6.84 & 9.29 & 18.00 & 41.67 \\
\hline Naineris laevigata & DF & 56.65 & 33.09 & 81.82 & 91.67 \\
\hline Grubeulepis westoni & DF & 8.79 & 11.31 & 29.82 & 50.00 \\
\hline Piromis sp. & $\mathrm{DF}$ & 4.88 & 9.29 & 14.73 & 25.00 \\
\hline Syllis gracilis & $\mathrm{C}$ & 28.32 & 27.12 & 52.36 & 75.00 \\
\hline Haplosyllis spongicola & $\mathrm{C}$ & 34.18 & 40.43 & 52.36 & 83.33 \\
\hline Syllis hialina & $\mathrm{C}$ & 13.67 & 15.67 & 38.91 & 58.33 \\
\hline Syllis sp. & $\mathrm{C}$ & 5.86 & 13.69 & 11.64 & 25.00 \\
\hline Ehlersileanira sp. & $\mathrm{C}$ & 10.74 & 19.00 & 25.45 & 33.33 \\
\hline Exogone lourei & $\mathrm{C}$ & 2.93 & 5.30 & 15.27 & 25.00 \\
\hline Exogone sp. & $\mathrm{C}$ & 6.84 & 14.53 & 18.73 & 25.00 \\
\hline Podarke obscura & $\mathrm{C}$ & 8.79 & 10.15 & 21.27 & 41.67 \\
\hline Fimbriosthenelais sp. & $\mathrm{C}$ & 5.86 & 9.35 & 13.64 & 25.00 \\
\hline Halosydna leucohyba & $\mathrm{C}$ & 10.74 & 13.65 & 29.45 & 50.00 \\
\hline Platynereis dumerilii & $\mathrm{C}-\mathrm{H}$ & 5.86 & 9.35 & 18.55 & 33.33 \\
\hline Laeonereis culveri & DF & 6.84 & 9.29 & 20.91 & 41.67 \\
\hline Nereis falsa & $\mathrm{C}$ & 4.88 & 6.03 & 18.55 & 33.33 \\
\hline Nereis riisei & $\mathrm{C}$ & 7.81 & 10.40 & 23.27 & 50.00 \\
\hline Terebella $\mathrm{sp}$. & DF & 28.32 & 29.76 & 45.45 & 75.00 \\
\hline Aricidea jeffreysi & DF & 14.65 & 16.67 & 29.64 & 66.67 \\
\hline Mediomastus californiensis & DF & 13.67 & 12.07 & 38.18 & 66.67 \\
\hline Capitella capitata & DF & 15.63 & 27.07 & 26.18 & 41.67 \\
\hline Pista cristata & DF & 1.95 & 4.56 & 2.73 & 8.33 \\
\hline
\end{tabular}

Trophic category (TC), density average (ind $/ \mathrm{m}^{2}$ ) (D), standard deviation (SD), Biological Index of Dominance (BID), species constancy (C), in percentage. DF: deposit feeder, C: carnivorous, H: herbivorous, O: omnivorous. 
of different species, as well as other related community parameters, such as diversity and evenness, difficult.

Lewis and Stoner (1981) obtained significant differences in abundance by using different sieve sizes ( 0.5 and $1.0 \mathrm{~mm}$ screen), collecting only $51-57 \%$ of the total macrofauna with the $1.0 \mathrm{~mm}$ screen. They also observed differences in abundances with core sizes (5.5, 7.6 and $10.5 \mathrm{~cm}$ in diameter), collecting more organisms per area sampled using the smallest core.

In this study, a $15 \mathrm{~cm}$ diameter core was chosen because relatively large organisms live in the grassbed community under investigation. These include as holothuroids, echinoids (Lytechinus variegatus (Lamarck 1816), Echinometra lucunter (Linnaeus 1758)), molluscs (sometimes bivalves cemented to each other), and crustaceans (Callinectes spp.), whose collection would be difficult or impossible using a smaller core. Also, the cores were taken at a depth of $25 \mathrm{~cm}$ due to the presence of Americonuphis magna (Andrews 1891), whose tubes can be buried at more than $60 \mathrm{~cm}$ in the sediment.

The range in the number of species recorded in Thalassia beds from the Atlantic American coast is relatively wide, varying from 21 to 51 species (Table 2), with an average of $35.71 \pm 10.71$ species. The range of densities is even wider, between 60 and $4409 \mathrm{ind} / \mathrm{m}^{2}$ ( $\bar{X}=1036.43 \pm 1554.99$ ). According to these average values, species richness and average density values obtained in this study are within the mean of the respective intervals.

The relatively high densities obtained in March-May and in June-July coincide with those observed in several studies carried out on invertebrates of the northeastern coast of Venezuela. Gómez et al. (1995) reported a maximum of reproduction between January and April, with a secondary peak from May to August. These two periods of reproduction coincide with the behavior of the up-welling in the northeastern coast of Venezuela that begins in November and reaches its greatest intensity from January to April and has another peak of lower intensity in July-August (Bonells et al. 1990).
Cluster analyses did not produce a clear separation among sampling months; however, the most important group (seven months) is constituted mainly by collections made during the warmer rainy period, which could suggest a certain influence of climatological parameters.

The high percentage of tubicolous species allows us to presume the efficiency of tubes against predators (Woodin 1978, 1981). Kinbergonuphis sp. has tubes that are very close to one another, providing it a more effective protection. Diopatra tridentata and $D$. cuprea have tubes on their external surfaces that incorporate alien material, mainly bivalve shell fragments, which protects them against possible predators. The absence of suspension feeder species can be attributed to the high turbidity in the zone (Stoner and Acevedo 1990) which interferes with the feeding and breathing processes of this trophic category. Also, the prevalence in the number of carnivorous species is obvious, to the detriment of deposit feeding species (40\%); however, the deposit feeders represent $68.51 \%$ of total abundance. In Stoner's (1980) study, $11 \%$ of the species were suspension feeders, $45 \%$ deposit feeders and $41 \%$ carnivorous and/or omnivorous; while Ibañez-Aguirre and Solís-Weiss (1986) reported $13 \%, 48 \%$ and $40 \%$ respectively.

The significant correlation obtained between the number of Thalassia shoots and polychaete abundance confirms that the greater biomass of this seagrass bears a greater macrofauna abundance and diversity, consequence of better protection against predators, which is consistent with the results of other studies (Stoner 1980, Lewis and Stoner 1983, Virnstein et al. 1983, Orth et al. 1984, Summerson and Peterson 1984, Schneider and Mann 1991, Connolly 1997). Further protection is provided by other biogenic structures such as the emergent tubes of several species, mainly onuphids, as well as other sessile invertebrates present in the collections, such as porifera and anemones.

In this study, the density of Thalassia shoots was lower than that recorded by IbañezAguirre and Solís-Weiss (1986) in Términos 
TABLE 2

Comparison of variables in Chacopata beach, Venezuela

\begin{tabular}{|c|c|c|c|c|c|c|c|c|}
\hline Author (s) & $\mathrm{AR}$ & NR & AS & $\mathrm{CD}$ & Mesh & $\mathrm{S}$ & Density & Locality \\
\hline Stoner (1980) & 445.36 & 12 & 5344.32 & 12 & 0.5 & 51 & 1204 & $\begin{array}{l}\text { Apalache Bay, } \\
\text { Florida }\end{array}$ \\
\hline Lewis and Stoner (1981) & 23.8 & 58 & 1380.4 & 10 & 0.5 & 24 & 1597 & $\begin{array}{l}\text { Apalache Bay, } \\
\text { Florida }\end{array}$ \\
\hline Lewis and Stoner (1981) & 23.8 & 58 & 1380.4 & 10 & 1.0 & 19 & 690 & $\begin{array}{l}\text { Apalache Bay, } \\
\text { Florida }\end{array}$ \\
\hline Lewis and Stoner (1981) & 45.4 & 30 & 1362.0 & 10 & 0.5 & 27 & 1046 & $\begin{array}{l}\text { Apalache Bay, } \\
\text { Florida }\end{array}$ \\
\hline Lewis and Stoner (1981) & 45.4 & 30 & 1362.0 & 10 & 1.0 & 20 & 503 & $\begin{array}{l}\text { Apalache Bay, } \\
\text { Florida }\end{array}$ \\
\hline Lewis and Stoner (1981) & 86.6 & 16 & 1385.6 & 10 & 0.5 & 28 & 920 & $\begin{array}{l}\text { Apalache Bay, } \\
\text { Florida }\end{array}$ \\
\hline Lewis and Stoner (1981) & 86.6 & 16 & 1385.6 & 10 & 1.0 & 21 & 478 & $\begin{array}{l}\text { Apalache Bay, } \\
\text { Florida }\end{array}$ \\
\hline Lewis and Stoner (1983) & 20.30 & 20 & 406 & 10 & 0.5 & 31 & 4409 & $\begin{array}{l}\text { Apalache Bay, } \\
\text { Florida }\end{array}$ \\
\hline $\begin{array}{l}\text { Vásquez-Montoya and } \\
\text { Thomassin (1983) }\end{array}$ & 188.69 & 1 & 188.69 & 22.5 & 1.8 & 30 & 89 & $\begin{array}{l}\text { Punta Galeta, } \\
\text { Panamá }\end{array}$ \\
\hline $\begin{array}{l}\text { Ibañez-Aguirre and Solís- } \\
\text { Weiss (1986) }\end{array}$ & 900 & 4 & 3600 & 20 & $?$ & 48 & 356 & $\begin{array}{l}\text { Laguna de } \\
\text { Términos, México }\end{array}$ \\
\hline Cruz-Ábrego et al. (1994) & 900 & 4 & 3600 & 20 & 0.5 & 34 & 60 & $\begin{array}{l}\text { Laguna de } \\
\text { Términos, México }\end{array}$ \\
\hline Greenway (1995) & 156.25 & 53 & 8281.25 & 10 & 2 & 21 & 148 & $\begin{array}{l}\text { Kingston Harbour, } \\
\text { Jamaica }\end{array}$ \\
\hline Jiménez et al. (2000) & 250 & 1 & 250 & 30 & 1 & 40 & 972 & $\begin{array}{l}\text { Bahía de Mochima, } \\
\text { Venezuela }\end{array}$ \\
\hline This study & 176.70 & 8 & 1413.6 & 25 & 0.5 & 35 & 989 & $\begin{array}{l}\text { Playa Chacopata, } \\
\text { Venezuela }\end{array}$ \\
\hline
\end{tabular}

Area of each replicate sample (AR, in $\left.\mathrm{cm}^{2}\right)$, number of replicate samples (NR), area sampled at each station (AS), core depth $\left(\mathrm{CD}\right.$, in $\mathrm{cm}$ ), mesh screen size (in $\mathrm{mm}$ ), species richness (S), density (ind $/ \mathrm{m}^{2}$ ) and sampling, from several studies on Thalassia beds on the American Atlantic coast.

Lagoon, Mexico (609), but higher than that recorded by Lewis and Stoner (1983) in Apalache Bay, Florida (184); however, in this last study, polychaete density was higher. When comparing the correlations between seagrass density or biomass and macrofauna abundance recorded in different studies, it is necessary to consider that each bed, including those located at the same latitude, possess its own unique conditions that differ from others. Water and sediment chemistry, species biology, inter- and intraspecific relationships, and the proximity of other environments (coralline, rocky, swamps, etc.), all influence the structure of the macrobenthos which can result in the dissimilar values of abundance and species richness recorded in the different studies. The influence of seagrass density or biomass on macrofaunal abundance or any other community parameter can be analyzed in the same bed, but the presence of other biogenic structures that provide refuge and 
microhabitats to other species must also be taken into consideration.

\section{RESUMEN}

Desde junio 2000 hasta abril 2001 se estudió la variación temporal de los poliquetos en una pradera de Thalassia testudinum en Chacopata, costa nororiental de Venezuela. Se recolectó un total de 1013 especímenes pertenecientes a 35 especies. La densidad mensual estuvo comprendida entre $387 \mathrm{ind} / \mathrm{m}^{2}$ (septiembre) y $1735 \mathrm{ind} / \mathrm{m}^{2}$ en mayo $\left(\overline{\mathrm{X}}=989 \pm 449 \mathrm{ind} / \mathrm{m}^{2}\right)$. La riqueza específica mensual fue mínima en agosto y septiembre (8) y máxima (25) en abril ( $\overline{\mathrm{X}}=18.00 \pm 5.29)$. La densidad promedio de tallos de Thalassia fue de $284 \pm 77.60$ tallos $/ \mathrm{m}^{2}$, con valores extremos en febrero (164) y mayo (422). La diversidad de especies presentó valores comprendidos entre 1.25 en agosto y 3.33 bits/ind en diciembre $(\bar{X}=2.47 \pm 0.64)$. Se apreciaron correlaciones positivas entre el número de tallos de Thalassia, la abundancia de poliquetos y la riqueza específica, así como de la riqueza específica con la abundancia de poliquetos y con la diversidad de especies. El número de especies recolectadas y la densidad promedio se encuentran en la zona media de los intervalos respectivos registrados en estudios similares. El elevado número de especies y organismos recolectados en marzo-abril y junio-julio puede ser atribuido a reclutamientos relacionados con el fenómeno de surgencia que se presenta en la costa oriental de Venezuela.

Palabras clave: macrofauna, bentos, Thalassia testudinum, Annelida, Polychaeta.

\section{REFERENCES}

Bonells, D., T. Okuda, J. Bonilla \& G. Cedeño. 1990. Algunas características hidrográficas en la región circunvecina a la Isla de Margarita, Venezuela. Bol. Inst. Oceanogr. Venezuela, Univ. Oriente 29: 27-41.

Connolly, R.M. 1997. Differences in composition of small, motile invertebrate assemblages from seagrass and unvegetated habitats in a southern Australian estuary. Hydrobiol. 346: 137-148.

Cruz-Ábrego, F.M., P. Hernández-Alcántara \& V. SolísWeiss. 1994. Estudio de la fauna de poliquetos (Annelida) y moluscos (Gastropoda y Bivalvia) asociada con ambientes de pastos marinos (Thalassia testudinum) y manglares (Rhizophora mangle) en la Laguna de Términos, Campeche, México. An. Inst. Cienc. del Mar y Limnol. UNAM 21: 1-13. den Hartog, C. 1967. The structural aspect in the ecology of sea-grass communities. Helgolander wiss. Meeresunters 15: 648-659.

Giesen, W.B.J.T., M.M. van Katwijk \& C. den Hartog. 1990. Eelgrass condition and turbidity in the Dutch Wadden Sea. Aqu. Bot. 37: 71-85.

Gómez, J.A., I. Liñero \& J. Fermín. 1995. Estudios ecológicos sobre Lima scabra (Born, 1768) (Pelecypoda: Limidae) en el Golfo de Cariaco, Venezuela. I. Censo y Relaciones Morfométricas. Bol. Inst. Oceanogr. Venezuela, Univ. Oriente 34 : 109-119.

Greenway, M. 1995. Trophic relationships of macrofauna within a Jamaican seagrass meadow and the role of the echinoid Lytechinus variegatus (Lamarck). Bull. Mar. Sci. 56: 719-736.

Hemminga, M.A., B.P. Koutstaal, J. van Soelen \& G.A. Merks. 1994. The nitrogen supply to intertidal eelgrass (Zostera marina). Mar. Biol. 118: 223-227.

Ibáñez-Aguirre, A.L. \& V. Solís-Weiss. 1986. Anélidos poliquetos de las praderas de Thalassia testudinum del Noroeste de la Laguna de Términos, Campeche, México. Rev. Biol. Trop. 34: 35-47.

Jiménez-Prieto, M., I. Liñero-Arana, J.P. Blanco-Rambla \& J. Fermín. 2000. Macrofauna asociada con Thalassia testudinum en Bahía de Mochima, Sucre, Venezuela. Rev. Biol. Trop. 48 (Supl. 1): 223-242.

Kitting, C.L. 1984. Selectivity by dense populations of small invertebrates foraging among seagrass blade surfaces. Estuaries 7: 276-288.

Kjerfve, B., J.O. Ogden, J. Garzón-Ferreira, E. JordánDahlgren, K. De Meyer, P. Penchaszadeh, W.J. Wiebe, J.D. Woodley \& J.C. Zieman. 1998. CARICOMP: A Caribbean Network of Marine Laboratories, Parks, and Reserves for Coastal Monitoring and Scientific Collaboration, p. 1-16. In B. Kjerfve (ed.). CARICOMP - Caribbean Coral Reef, Seagrass and Mangrove Sites. UNESCO, Paris, France.

Lewis, J.B. 1977. Processes of organic production on coral reefs. Biol. Rev. 52: 305-347.

Lewis, F.G. \& A.W. Stoner. 1981. An examination of methods for sampling macrobenthos in seagrass meadows. Bull. Mar. Sci. 31: 116-124.

Lewis, F.G. \& A.W. Stoner. 1983. Distribution of macrofauna within seagrass beds: an explanation for patterns of abundance. Bull. Mar. Sci. 33: 296-304.

McCloskey, L.R. 1970. The dynamics of the community associated with a marine scleractinian coral. Int. Revue. Ges. Hydrobiol. 55: 13-81. 
O’Gower, A.K. \& J.W. Wacasey 1967. Animal communities associated with Thalassia, Diplanthera, and sand beds in Biscayne Bay. I. Analysis of communities in relation to water movements. Bull. Mar. Sci. 17: 175-210.

Orth, R.J., K.L. Heck Jr. \& J. Van Montfrans. 1984. Faunal communities in seagrass beds: a review of the influence of plant structure and prey characteristics on predator-prey relationships. Estuaries 7: 339-350.

Orth, R.J. \& K.A. Moore. 1986. Seasonal and year to year variations in the growth of Zostera marina L. (eelgrass) in the lower Chesapeake Bay. Aq. Bot. 15: 117-131.

Pedersen, M.F. \& J. Borum. 1993. An annual nitrogen budget for a seagrass Zostera marina population. Mar. Ecol. Prog. Series 101: 169-177.

Pielou, E.C. 1966. The measurement of diversity in different types of biological collections. J. Theor. Biol. 13: 131-144.

Schneider, F.I. \& K.H. Mann. 1991. Species specific relationships of invertebrates to vegetation in a seagrass bed. I. Correlational studies. J. Exp. Mar. Biol. Ecol. 145: 101-117.

Short, F.T. 1987. Effects of sediment nutrients on seagrasses: Literature review and mesocosm experiments. Aquat. Bot. 27: 41-57.

Stoner, A.W. 1980. The role of seagrass biomass in the organization of benthic macrofaunal assemblages. Bull. Mar. Sci. 30: 537-551.
Stoner, A.W. \& C. Acevedo. 1990. The macroinfaunal community of a tropical estuarine lagoon. Estuaries 13: 174-181.

Summerson, H. \& C. Peterson. 1984. Role of predation in organizing benthic communities of a temperate-zone sea grass bed. Mar. Ecol. Prog. Ser. 15: 63-77.

Terrados, J., C.M. Duarte, M.D. Fortes, J. Borum, N.S.R. Agawin, S. Bach, L. Kamp-Nielsen, W.J. Wenworthy, O. Geertz-Hansen \& J. Vermaat. 1998. Changes in community structure and biomass of seagrass communities along gradients of siltation in SE Asia. Estuar. Coast. Shelf Sci. 46: 757-768.

Vásquez-Montoya, R. \& B. Thomassin. 1983. Contribución al conocimiento de los anélidos poliquetos de las praderas de Thalassia testudinum y Halodule sp. del sector de Punta Galeta (Panamá, Provincia de Colón). An. Inst. Cienc. Mar Limnol. UNAM 10: 1-10.

Virnstein, R.W., P.S. Mikkelsen, K.D. Cairns \& M. Capone. 1983. Seagrass beds versus sand bottoms: the trophic importance of their associated benthic invertebrates. Florida Sci. 46: 67-82.

Woodin, S.A. 1978. Refuges, disturbance, and community structure: a marine soft-bottom example. Ecology 59: 274-284.

Woodin, S.A. 1981. Disturbance and community structure in a shallow water sand flat. Ecology 62: 1052-1066. 